\title{
The Information Asymmetry between Management and Rank-and-File Employees: Determinants and Consequences
}

\begin{abstract}
:
We investigate whether information possessed by rank-and-file employees is incorporated in top managers' expectations and decisions. Using employees' predictions of their company's business outlook from Glassdoor.com to measure the employees' information set, and using management earnings forecasts to measure management expectations, we show that management expectations incorporate employees' information only partially. This intrafirm information asymmetry is lower when top managers are more experienced and internally engaged and when employees are more satisfied with senior management, firm culture, and their compensation; and higher in companies that are more decentralized, have internal control weakness, and poorly incentivize their employees. Further analyses suggest that our results are not driven by managers’ strategically choosing not to use employees' information in their forecasts. Finally, we document that firms with large discrepancies between management forecasts and employee outlook have poorer future performance and a higher likelihood of CEO turnover.
\end{abstract}




\section{INTRODUCTION}

Financial accounting generally assumes that top managers make disclosure decisions based on all information available in the firm. In contrast, managerial accounting recognizes information asymmetry — defined as differences in knowledge between top managers and employees—as one of two key "primitives" that drive organizational design (Hofmann and Van Lent 2015). Though theoretically important, intrafirm information asymmetry has been difficult to measure empirically. This has prevented researchers from addressing basic questions about its existence and significance and slowed their progress toward understanding its determinants and consequences.

The primary challenge in measuring this information asymmetry is that employees' information is generally unobservable to researchers. We overcome this challenge by exploiting the database from the popular job site Glassdoor.com. On this site, company employees can choose from three options to predict company performance six months into the future: "get better," "stay the same,” or "get worse” (“employee outlook," henceforth). We code these predictions $+1,0$, and -1 , respectively, and average them across all current employees to obtain a measure of the employees' information set. Our estimate of intrafirm information asymmetry is the slope coefficient in a regression of management forecast errors on employee outlook issued within 30 days prior to the issuance of the management forecast. ${ }^{1}$ If management has access to employees' information, then its forecasts will fully incorporate the information embedded in employee outlook, and the slope coefficient on employee outlook will be zero.

Our sample consists of 153,227 individual employee predictions and 11,686 annual management forecasts for 994 unique firms from May 2012 to September 2017. Controlling for

\footnotetext{
${ }^{1}$ Our results throughout the paper are robust if we use a 60-day or 90-day instead of 30-day window.
} 
other determinants of management forecast error, we find a positive and significant coefficient on Outlook, suggesting that higher (lower) employee outlook is associated with more pessimistic (optimistic) management forecasts. This finding is consistent with top management not possessing all the information held by employees. In terms of economic significance, one standard deviation increase in Outlook increases the management forecast error by 0.05 percentage points, which is equivalent to $51 \%$ of our sample mean forecast error.

We next explore whether the information asymmetry between management and employees is alleviated by CEO’s experience and internal engagement, employees' satisfaction, and organizational factors such as centralized decision making, better internal control, and use of stock options to incentivize employees.

First, we posit that more experienced and internally focused CEOs are generally more knowledgeable about firm operations and more engaged with company employees, resulting in lower information asymmetry. We define experienced CEOs as company founders or CEOs who are later in their tenure, and define internally focused CEOs as ones who attend fewer investor conferences. Consistently, we find that both of these CEO attributes are associated with lower information asymmetry. This is a novel finding. Unlike prior research, which suggests that longer tenure increases CEO entrenchment, our results show that longer tenure increases CEOs' ability to collect and process internal information. And while existing studies document that externally oriented CEOs help improve firm-investor relations (Green et al. 2014), we find that these CEOs are less informed about their companies’ internal affairs.

Second, we posit that higher employee satisfaction increases employees' motivation and trust in management, and that this, in turn, makes employees more willing to communicate information to superiors-resulting in lower information asymmetry. Using Glassdoor.com- 
solicited employees’ ratings of senior management, firm culture and values, and employee compensation and benefits as measures of satisfaction, we find that the association between forecast error and outlook is lower when employees are more satisfied. This is consistent with more satisfied employees broadening the information set used for managerial decisions, and extends prior work on the relation between employee satisfaction and company performance (Edmans 2011).

Third, drawing on prior work in managerial accounting (Feng et al. 2009; Li et al. 2014; Hofmann and Lent 2015), we predict that information asymmetry is greater in more decentralized firms (because information aggregation is more challenging in these firms), firms with less effective internal control systems (because weaker controls exacerbate informationprocessing errors and delays), and firms with less employee stock options (because employees in these firms have less incentive to communicate private information to their superiors). Our results are consistent with these predictions, and provide systematic empirical evidence in support of theoretical research that models the effect of these firm factors on internal information communication.

An alternative explanation for the predictive value of employee outlook with respect to management forecast errors is that management has access to the employees’ information but chooses not to use it. We present two sets of results that are inconsistent with this explanation. First, we show that top managers do not incorporate positive outlook even when they have strong economic incentives to do so-specifically, in firms with high financial distress, external financing needs, high product market competition, and high insider selling. Second, we show that top managers’ own purchases, which are highly likely to be information-driven, are unrelated to employee outlook. 
Finally, we test the consequences of the information asymmetry between top management and employees. When top managers do not acquire and use employees' information in operational and investment decisions, firm performance is likely to suffer. We regard the manager-employee expectation gap as large when management forecast error is in the most optimistic (pessimistic) quintile and employee outlook is in the most pessimistic (optimistic) quintile in any of the past three years. We find that, relative to other firms, firms with large manager-employee expectation gaps experience a decline in current year’s ROA (Tobin’s Q) that is equivalent to 16 (10) percent of sample mean. In addition, the likelihood of CEO turnover in these firms increases by 3.7 percentage points, representing an increase of 48 percent from the average turnover rate for firms without large expectation gaps.

We extend managerial accounting research both by quantifying the information asymmetry between top management and company employees and by documenting its determinants and consequences. A nascent literature studies intrafirm information asymmetry among the individuals atop the corporate hierarchy. This includes Li et al. (2014) and Ke et al. (2018), who examine information asymmetry within top management teams, and Chen et al. (2018), who consider information asymmetry between top management and divisional managers. However, information asymmetries are not limited to a company’s uppermost levels. In today's large, multilayered organizations, information frictions prevent employees at all levels from sharing information with their superiors. Our measure of information asymmetry, constructed from social media disclosures by employees at all levels, captures this pervasiveness.

Our study also contributes to the disclosure literature. Our finding that managers inefficiently use available information from employees extends prior work on management forecast inefficiency, which focused on managers' use of existing information from financial 
reports (e.g., Gong et al. 2009; Gong et al. 2011). Additionally, our finding that large manageremployee expectation gaps incrementally predict poor company performance and adverse CEO career outcomes is consistent with prior results linking forecast inaccuracy to poor performance and CEO turnover (Lee et al. 2012; Goodman et al. 2014). Furthermore, we extend this line of literature by identifying information asymmetry between company employees and top management as a culprit of forecast inaccuracy. Our results therefore have distinct implications for researchers and managers alike.

Our study fundamentally differs from other studies that also use Glassdoor.com data (e.g., Hales et al. 2018; Huang et al. 2018; Sheng 2018). While previous papers use Glassdoor data to study how employees' social media disclosures reveal new information in capital markets, we use it to study the flow of information within the firm—-from company rank-and-file employees to top management.

The rest of the paper is organized as follows. In Section II, we review the literature and develop our hypotheses. In Section III, we discuss our sample and provide descriptive statistics. In Section IV, we present the results of our analyses. We conclude in Section V.

\section{LITERATURE REVIEW AND HYPOTHESIS DEVELOPMENT}

\section{Related Literature}

Organizational theories have long recognized that knowledge relevant to decision making is spread among employees across different hierarchies within a firm (Aghion and Tirole 1997). A key objective of organizational design is to ensure that information available throughout the organization is collected and used in centralized decision making (Baiman et al. 1995; Brickley et al. 2009). 
Motivated by the economic and organizational theories, prior research identifies the factors that influence internal information acquisitions and communications. A number of studies suggest that effective management controls, including SOX 404 internal controls, enterprise systems, and risk-based forecasting and planning processes, facilitate information acquisition and processing and hence improve management forecast accuracy (Feng et al. 2009; Dorantes et al. 2013; Ittner and Michels 2017). These studies focus on firm general information environment and do not touch upon the two distinct channels through which internal information quality can be improved, i.e., information production and information sharing.

Looking beyond control systems, recent research examines how "human factors" affect internal information environment. For example, Ke et al. (2018) propose that social connections within top management teams foster teamwork and information sharing, and document that social connections are associated with higher management forecast accuracy. Garrett et al. (2014) find that employees' trust in management is associated with higher financial reporting quality, consistent with trust improving information production and sharing. While both studies theorize that greater information sharing is one possible mechanism for their observed results, they do not provide empirical evidence on the mechanism because they lack direct measures that assess the extent of information sharing.

In a related study, Chen et al. (2018) focuses exclusively on information sharing. They develop a direct measure of information asymmetry between top and divisional managers using the difference in their respective trading profits on their own company's stock and find that their measure is associated with various aspects of management forecast quality and error-driven accounting restatements. 
The above discussion shows that none of the existing studies have provided direct evidence on the information asymmetry between top managers and rank-and-file employees. We fill this void by establishing a direct measure of such information asymmetry using employee predictions of company performance from Glassdoor.com to proxy for employee information.

\section{Hypothesis Development}

\section{Information Asymmetry between Top Management and Rank-and-file Employees}

Company employees acquire valuable information through interactions with customers, suppliers, and fellow employees. However, because of non-trivial information costs and agency costs, some of this information cannot be transmitted to top management. Top managers may lack the experience or motivation to collect information from rank-and-file employees, and employees may withhold or distort information due to distrust in management, career concerns, or other motives (Prendergast 1993; Garrett et al. 2014). Organizational factors such as a decentralized organizational structure and ineffective internal information systems could also limit information transmission within a firm.

It is possible that employees possess important information that is unknown to top managers but employee predictions of company performance on Glassdoor do not capture this information. There are at least two reasons for this. First, it is possible that lower-level employees base their predictions mostly on forecasts by upper management and not their own private information. Second, given that each employee's job composes only a small piece of the company's business, an employee may frame the forecasting problem too narrowly and overemphasize information about her part of the company, resulting in less informative predictions. Therefore, whether employee outlook can capture valuable information that is only available in the bottom corporate hierarchies is an empirical question. 


\section{Determinants of Internal Information Asymmetry}

As suggested by prior research, individuals have limited capability to gather, absorb, and process information (Sah and Stigliz 1986). Accordingly, we identify attributes that are likely to influence the CEO's ability to assimilate and aggregate information across corporate hierarchies. Specifically, we use founder status and tenure to measure CEO experience with the firm, and whether the CEO is internally or externally focused to measure CEO involvement in firm operations. Founder CEOs generally possess in-depth organizational knowledge due to their long-term ownership of, and reputational and emotional ties to, the company (Demsetz and Lehn 1985). Thus, firms with founder CEOs are likely to have lower manager-employee expectation gaps. Similarly, CEO tenure plays a role in a CEO’s ability to extract employee-level information, because relationship building with firm employees takes time (Li et al. 2014). Therefore, CEOs with longer tenure are likely to be more familiar with the firm's business and their subordinates, leading to lower information asymmetry. Additionally, internally focused CEOs - CEOs who devote more time to interactions with employees and less time to external affairs-are likely to obtain more information within the firm, resulting in lower information asymmetry.

We next examine how employee satisfaction—as reflected in Glassdoor.com employee assessments of senior management, culture and values, compensation and benefits, and career opportunities_-affects the information asymmetry between management and employees. Employee satisfaction should facilitate information sharing, because employees who are more satisfied with their management and their company are more willing to reveal private information to management; those who are less satisfied are more likely to postpone delivering bad news, to avoid being perceived as poor performers. Therefore, we predict that the manageremployee expectation gap decreases with employee satisfaction. 
Finally, we examine how firm characteristics related to organizational structure, internal controls, and employee incentive structures affect the information asymmetry between management and employees. In more decentralized firms, top management is less likely to have all the information generated from the bottom, as information transfer and aggregation are more challenging (Garrett et al. 2014). Ineffective internal controls increase information processing errors and reduce the timeliness of information transfers, leading to greater information asymmetry (Feng et al. 2009). In addition, employee stock options that link employee compensation with firm performance can be an effective mechanism to promote information sharing, because employees who receive options have an additional incentive to boost firm performance and hence are more willing to reveal their private information.

\section{Consequences of Internal Information Asymmetry}

Decision theory has established that the quality of the information on which decisions are based affects decision quality and outcomes (Gallemore and Labor 2015). Firms recognize that information held by their employees is critical to their operational and investment decisions. Corporations such as Ford Motor Company, Best Buy, and Hewlett-Packard go so far as to operate internal prediction markets, where employee participants trade virtual securities on event outcomes, in order to extract employees’ information on product demand, project completion, R\&D, and other areas (Wolfers and Zitzewitz 2004; Dvorak 2008; Cowgill and Zitzewitz 2015). Failure to incorporate such information from employees can lead to inefficient managerial decisions. Therefore, we predict that greater information asymmetry between management and employees leads to lower firm performance in the future.

We also examine whether managers’ failure to incorporate employee information affects CEO career outcome. If a failure to incorporate employee information leads to poor managerial decisions and lower firm performance, then the board of directors should punish the managers 
for this, increasing the likelihood of CEO turnover. This prediction is consistent with Lee et al. (2012). They suggest that management forecast accuracy signals managers' ability to anticipate and respond to future events, and find that CEO turnover is positively associated with absolute value of management forecast errors when firm performance is poor. More importantly, our prediction identifies a specific source of management forecast inefficiency: the failure to incorporate employee information.

\section{DATA AND RESEARCH DESIGN}

\section{Glassdoor Data and Sample Selection}

Launched in 2008, Glassdoor.com is a large website where current and former employees voluntarily, directly, and anonymously review companies and their management. Each company review contains various five-point scale ratings: an overall rating on the company as well as optional ratings on senior management, career opportunities, compensation and benefits, work/life balance, and culture and values. ${ }^{2}$ Importantly, since May 2012, employees have been asked to assess their companies’ six-month business outlook by choosing one of three options: "get better,” "stay the same,” or "get worse.” Our initial data from Glassdoor include more than 1 million employee outlook reviews for 6,790 public firms from May 2012 to September 2017. After merging the data with Compustat universe using both ticker symbols and company names, we have 928,725 outlook reviews (506,691 of which are from current employees) for 5,200 unique firms.

We collect management forecasts of annual earnings issued during years 2012-2017 from the I/B/E/S guidance database. We retain management earnings forecasts issued before and

\footnotetext{
2 The review also specifies whether the employee approves the CEO, and whether she recommends the company to a friend.
} 
on the fiscal year end of the forecasting year, and for which we can find actual earnings per share information, resulting in a total of 24,609 forecasts. For each forecast, we identify business outlook provided by current employees within 30 days prior to the forecast issuance, and find matched outlook for 11,937 management earnings forecasts. Lastly, requiring sufficient Compustat control variables, stock return information from CRSP, and analyst following information from I/B/E/S, our final sample consists of 11,686 annual management forecasts from 3,520 firm-years.

\section{Research Design}

We examine the expectation gap between top management and rank-and-file employees by estimating the following ordinary least squares (OLS) regression model:

$$
\text { MFE }_{i, t+1}=\beta_{0}+\beta_{1} \text { Outlook }_{i, t+1}+\beta \text { Controls } i, t+\sum \text { Industry FE }+\sum \text { Time FE }+\varepsilon_{i, t+1}
$$

where $M F E$ is management forecast error, measured as actual earnings per share for year $t+1$ minus management earnings forecast for year $t+1$, scaled by the closing price at the end of fiscal year t. If management issues a range forecast, we use the midpoint of the range. Outlook is the average value of the outlook assessments provided by current employees within 30 days prior to the issuance date of the management forecast.

Controls represent a vector of variables that could be correlated with both MFE and Outlook. We control for firm characteristics, such as size (Size), market-to-book ratio (MTB), and leverage ( $L E V)$, and for performance-related variables, including current return on assets $(R O A)$, sales growth (SG), incidence of loss (Loss), level of accruals (TACC), and stock returns (RET). We include earnings volatility (STDROA) and return volatility (STDRET) to control for uncertainty (Rogers and Stocken 2005). We control for litigation risk (LitiRisk) and analyst coverage (LogNUMA), as greater litigation risk may deter managers from issuing optimistic 
forecasts, and greater analyst coverage brings more public scrutiny on management disclosure (e.g., Francis et al. 1994; Lang and Lundholm 1996). Finally, we control for forecast horizon (Horizon), because longer horizon forecasts are harder to forecast and more likely to be optimistic. We provide detailed definitions of all the variables in the Appendix. To mitigate the influences of outliers in the data, we winsorize the top and bottom one-percentiles of all continuous variables except Outlook. ${ }^{3}$ We cluster standard errors at the firm and year levels to address cross-sectional and time-series dependence (Gow et al. 2010) and include both year and industry fixed effects in our regressions.

If managers do not have access to employees' information, they will underreact to such information in forecasting earnings, leading to a positive coefficient on Outlook. ${ }^{4}$

After investigating the basic relation between management forecast errors and employee outlook, we further examine how various CEO-, employee-, and firm-related factors affect the expectation gap between management and employees. Specifically, we identify the effect of each factor by estimating the following regression model:

$$
\begin{aligned}
\text { MFE }_{i, t+1}= & \beta_{0}+\beta_{1} \text { Outlook }_{i, t}+\beta_{2} \text { Factor }_{i, t}+\beta_{3} \text { Outlook }_{i, t} * \text { Factor }_{i, t}+\beta_{4} \text { Controls }_{i, t}+ \\
& \text { SIndustry FE }+\sum \text { Time FE }+\varepsilon_{i, t+1}
\end{aligned}
$$

Where Factor represents a proxy for a CEO-, employee-, or firm-related factor (to be discussed in detail in Section IV). Our variable of interest is Outlook * Factor. A positive (negative) coefficient on the interaction term indicates that the factor exacerbates (ameliorates) the information asymmetry.

\footnotetext{
${ }^{3}$ We do not winsorize outlook because individual outlook is coded as $-1,0$, and 0 and not subject to outlier and error problems.

${ }^{4}$ Based on our definition of management forecast error, a positive error indicates management pessimism (optimism).
} 


\section{EMPIRICAL RESULTS}

\section{Summary Statistics}

Table 1 reports summary statistics for our sample data. The mean and median values of MFE are 0.0010 and 0.0015 , respectively. These positive values indicate that, on average, management forecasts are pessimistic. This is consistent with a trend toward increasingly pessimistic range earnings forecasts documented in Ciconte et al. (2014). The mean (median) value of Outlook is 0.31 (0.33), indicating that, on average, employees expect firm performance to improve. Outlook varies substantially, increasing from 0.0 in the first quartile to 0.8 in the third quartile.

The mean (median) market capitalization in our sample is 5.8 (5.7) billion, with a marketto-book ratio of 4.7 (3.1). Our sample firms are profitable, with an average return on assets of $6.2 \%$, sales growth of $7.5 \%$, and stock returns of $16.8 \%$. Both the mean and median values of horizon are 0.58 , which is equivalent to 211 days between the management earnings forecast issuance date and forecasting period end. Finally, the mean (median) value of the number of analyst following is $13(14)$.

\section{Predicting Management Forecast Errors Using Employee Outlook}

Table 2 reports the results on the relation between management forecast errors and employee outlook. We present three specifications: (1) control variables excluded, (2) control variables included, and (3) replacing the midpoint with the upper value of the range forecast to compute management forecast error. We include specification (3) because Ciconte et al. (2014) suggest that the upper bound of range forecasts is closer to managers' true expectations than the midpoint in recent years. The coefficient estimates on Outlook are positive and statistically significant at the $1 \%$ level in all specifications, consistent with management's underreaction to 
the information embedded in employee outlook. In terms of economic significance, based on specification (2), a one-standard-deviation increase in Outlook is associated with an increase of MFE by 0.0005 , which is about 51 percent of sample mean MFE. ${ }^{5}$

Turning to control variables, we find a negative and significant coefficient on ROA, suggesting that managers over-extrapolate past performance in forecasting future earnings. The coefficient on TACC is negative and significant, consistent with a prior finding that managers overreact to accounting accruals (Gong et al. 2009). We also find that firms with volatile earnings have less optimistic forecasts, while firms with volatile stock returns have more optimistic forecasts. Finally, the coefficient on Horizon is negative and significant, consistent with our expectation that management forecast optimism increases with forecast horizon.

\section{Cross-sectional Analysis: CEO Attributes}

In this subsection, we identify CEO attributes that are likely to be associated with the expectation gap between management and employees. Managers who are more experienced with the firm or more engaged in firm operations should have greater organizational knowledge and should hence acquire more employee-level information. Therefore, we expect a weaker association between management forecast error and employee outlook when firm CEOs are more experienced or engaged with the firm. We use CEO founder status and tenure to measure CEO experience, and whether the CEO is internally or externally oriented to measure CEO engagement. Specifically, we construct three indicator variables: CEO_Founder is equal to one if the CEO is a founder of the company, and zero otherwise; CEO_Tenure is equal to one if the number of years the CEO has worked for the company is above our sample median, and zero otherwise; and ExternalOriented_CEO is equal to one if the number of investor conferences the

\footnotetext{
${ }^{5}$ As a reference, the economic effect of outlook is comparable to that of accruals as examined in Gong et al. (2009) and is about half the effect of earnings volatility, a known key determinant of management forecast error.
} 
CEO attends in a year is above our sample median, and zero otherwise. Panel A of Table 3 describes the summary statistics of the three proxies. We find that $18.5 \%$ of CEOs in our sample are founders, the mean (median) tenure of CEOs is 7.4 (5.3) years, and CEOs attend 6.9 conferences per year on average.

Panel B of Table 3 reports results on how the manager-employee expectation gap varies with the three CEO attributes. In column (1), the coefficient on Outlook*CEO_Founder is negative and significant $(-0.0029, \mathrm{t}=2.01)$, consistent with our prediction that founder CEOs gather more employee information and incorporate it in their earnings forecasts. In Column (2), the coefficient on Outlook*CEO_Tenure is also negative and significant, suggesting that CEOs with longer tenure are likely to have more employee information. In Column (3), Outlook*ExternalOriented_CEO loads significantly positive, implying that CEOs who spend more time on outside communications have less internal knowledge and therefore incorporate less employee information in earnings forecasts.

\section{Cross-sectional Analysis: Employee Satisfaction}

We next examine how employee satisfaction affects the expectation gap between management and employees. Employees who are more satisfied with their management and firm should be more willing to reveal and communicate their private information to management. Therefore, we predict that the manager-employee expectation gap decreases with employee satisfaction. We examine various aspects of employee satisfaction available from Glassdoor, including employee assessments of senior management; culture and values; compensation and benefits; and career opportunities.

Table 4 reports our empirical results. Panel A reports the descriptive statistics of employee satisfaction scores that are measured based on a five-point scale, with "most satisfied" 
being five and "least satisfied" being one. The average score ranges from 2.97 for senior management to 3.35 for compensation and benefits. The median score ranges from 3.00 for senior management to 3.42 for culture and values. The descriptive statistics indicate that, on average, employees are neutral towards their management and company.

Panel B presents the regression results. Each proxy for a specific aspect of employee satisfaction is measured as an indicator variable equal to one if the average value of the employee assessments is above the sample median. We find that the interaction terms on employee satisfaction proxies and outlook are negative and significant in Columns (1) to (3), suggesting that the expectation gap is lower when employees have higher assessments of senior management; culture and values; and compensation and benefits. The coefficient on the interaction term in Column (4) is negative but insignificant. In Column (5), we conduct principal component analysis to construct an overall satisfaction score (SatisfFactor) based on all four aspects of employee satisfaction, and find that the interaction term between SatisfFactor and Outlook loads negatively and significantly $(-0.0006, t=2.49)$. The overall results are consistent with our prediction that employee satisfaction encourages information sharing by employees and reduces the expectation gap between them and management.

\section{Cross-sectional Analysis: Firm Characteristics}

Finally, we expect that the manager-employee expectation gaps are greater for decentralized firms and firms with internal control weakness, and lower for firms with more employee stock options. To measure decentralization, we first conduct principal component analysis based on the number of business segments, the number of geographic segments, and the number of employees, and obtain the first factor. ${ }^{6}$ We construct Decentralization as an indicator

\footnotetext{
${ }^{6}$ Principal component analysis reveals that a single factor adequately explains the variation in these three variables.
} 
variable equal to one if this factor is above the sample median, and zero otherwise. Similarly, IC_Weakness is an indicator variable equal to one if a firm discloses an internal weakness in the fiscal year, and zero otherwise; and EmpStockOption is an indicator variable equal to one if the non-executive employee stock option is above the sample median, and zero otherwise.

Table 5 reports our results. Panel A reports the descriptive statistics on firm characteristics. Firms in our sample on average have 2.6 business segments, 3.4 geographic segments, 35,766 employees, and non-executive stock options that account for $3.6 \%$ of the number of shares outstanding. Also, 3.6\% of our sample firms have internal control weakness. Panel B reports the regression results. In Column (1), the coefficient on the interaction term between Outlook and Decentralization is positive and significant, consistent with our prediction that the information gap is greater in more decentralized firms. In Column (2), the interaction term between Outlook and IC_Weakness loads significantly positive, indicating that firms with ineffective internal controls have greater information gaps between management and employees. In Column (3), the interaction term between EmpStockOption and Outlook loads significantly negative, suggesting that the use of employee stock options facilitates employee information sharing and hence results in a lower information gap.

\section{Unintentional vs. Intentional Forecasting Behavior}

\section{Managerial Incentive Analysis}

We attribute the positive association between management forecast error and employee outlook to managers’ lacking important information held by rank-and-file employees. However, this positive association could also arise if managers do possess the information from rank-andfile employees but choose not to incorporate it in their earnings forecast for strategic reasons. We 
address this alternative explanation by examining whether managers use outlook information in cases where they have strong incentives to do so.

Prior research identifies various incentives that motivate managers to bias their earnings forecasts, including financial distress, external financing, product market competition, and insider trading. Financial distress drives managers to boost market expectations with optimistic forecasts due to career concerns (Frost 1997; Koch 2002). External financing motivates managers to issue optimistic forecasts to facilitate security issuance and increase cash proceeds (Frankel et al. 1995; Lang and Lundholm 2000). High industry competition also encourages managers to disclose good news in their forecasts, to signal managers' ability. Finally, managers are more likely to disclose good news before selling firm stocks, because this boosts insidertrading profitability (Noe 1999; Aboody and Kasznik 2000).

We examine the relation between management forecast error and positive employee outlook in subsamples of high financial distress, high external financing, high industry competition (measured by low market concentration), and high insider selling. We expect that managers have incentives to incorporate good news from employees in all four subsamples. Columns (1)-(4) of Table 6 report the results. Consistently, we find that the coefficients on Outlook are positive and significant across all four columns, indicating that managers do not fully incorporate the information in positive employee outlook in their earnings forecasts even when they have strong incentives to do so. The results suggest that managers' underreaction to employee outlook is most likely caused by their lack of awareness of it and not by their intentionally excluding it from earnings forecasts. 


\section{Insider Trading Analysis}

We also examine whether managers’ trades of their own companies’ stocks are associated with employee outlook. Insider trades should capture managers’ private information sets and be free or nearly free of intentional bias. Therefore, we infer that managers do not have employee information if their trades are not associated with employee outlook. We focus on insider purchases only, because purchases are more likely to be information-driven, whereas sales can also be driven by diversification or liquidity needs.

Table 7 reports the results on the relation between insider purchases and employee outlook. In Column (1), Purchase_Indicator is an indicator variable equal to one if the CEO or CFO makes any open market purchases in the 30 days following the date of issuance of the management forecast. ${ }^{7}$ In Columns (2) and (3), Purchase_Quantity is the abnormal number of shares purchased by the CEO and CFO, measured as the difference between shares purchased in the 30 days after the forecast issuance date and shares purchased in the 90 days before the forecast issuance date, scaled by the number shares outstanding. We use abnormal purchases to control for firm-specific factors that impact insider trading. In Column (2), we code

Purchase_Quantity as zero for observations with no trading activities. In Column (3), we exclude observations with no trading activities. The control variables in all three columns are the same as in Table 2. In all three columns, insider purchases are not associated with employee outlook, providing further evidence that managers do not possess the information embedded in employee outlook. ${ }^{8}$

\footnotetext{
${ }^{7}$ Because employee outlook is the average outlook issued within 30 days prior to the management forecast date, the CEO and CFO trades in our tests are measured after employees post their outlook predictions on Glassdoor.

${ }^{8}$ The coefficients on total accruals are negative and significant, consistent with the prior finding that managers understand the implication of accruals and trade accordingly (Beneish and Vargus 2002). The significant result on accruals also suggests that the insignificant coefficients on Outlook are unlikely to have been caused by a lack of statistical power.
} 


\section{Consequences of Manager-Employee Expectation Gap}

\section{Future Performance Analysis}

Information held by firm employees is critical to operational and investment decisions. Failure to incorporate valuable employee information can lead to inefficient managerial decisions and lower future performance. Therefore, we expect that firms with larger information asymmetry between management and employees have lower performance in the future.

We measure firm performance using both accounting performance (ROA) and market valuation (TobinQ). To proxy for the manager-employee expectation gap, we construct an indicator variable (LargeGap) equal to one if management forecast error is in the most optimistic (pessimistic) quintile and employee outlook is in the most pessimistic (optimistic) quintile in any of the previous three years, and zero otherwise. We regress firm future performance on LargeGap. We control for various firm characteristics, including size, leverage, return on assets, sales growth, tangible assets, $R \& D$, return volatility, and institutional ownership. We control for management forecast accuracy (AbsMFE), as Goodman et al. (2014) suggest that forecast accuracy is associated with investment efficiency. We control for employee satisfaction, because Edmans (2011) suggests that employee satisfaction improves firm performance. Finally, we control for employee outlook in order to separate the predictive value of outlook on future performance from the economic consequence of the manager-employee expectation gap. For consistency with the definition of LargeGap, we use the average value from the past three years for all control variables.

Table 8 reports our results. Panel A reports descriptive statistics of the sample used for future performance analysis. Firms in this sample have a mean ROA of 0.05 and Tobin's Q of 2.26. About $16 \%$ have a large manager-employee expectation gap in the past three years. 
Panel B reports regression results. We find that the coefficient on LargeGap is negative and significant when either $R O A$ or TobinQ is used as the dependent variable and whether or not Outlook is included in the regression. These results are consistent with our prediction that the manager-employee expectation gap is associated with poorer future accounting performance and firm valuations. In terms of economic magnitude, as we move from firms without a large gap to firms with a large gap, we find that $R O A$ (TobinQ) decreases by $0.8 \%(0.231)$, equivalent to $16 \%$ (10\%) of the sample mean. With respect to control variables, we find that management forecast accuracy and employee overall satisfaction are positively associated with future performance, as suggested in prior studies (Goodman et al 2014; Edmans 2011). Outlook is also positively associated with future performance, consistent with Hales et al. (2018) and Huang et al. (2018).

\section{CEO Turnover Analysis}

We also examine whether failure to incorporate employee information affects CEO career outcome. If CEOs' ability to acquire and incorporate employee information in managerial decisions is critical to firm success, then failure to incorporate such information should increase the likelihood of CEO turnover. Lee et al. (2012) suggest that management forecast accuracy signals managers' ability to anticipate and respond to future events, and find that CEO turnover is positively associated with the absolute value of management forecast errors when firm performance is poor. We examine whether a specific source of management forecast inefficiency — the failure to incorporate employee information — has an incremental effect on CEO turnover beyond the effect documented in Lee et al. (2012).

Following Lee et al. (2012), we control for a list of determinants of CEO turnover, including firm accounting and stock performance; size; earnings volatility and return volatility; institutional ownership; and CEO age and power. In addition, we control for forecast accuracy, 
to distinguish our effect from that of forecast accuracy. Finally, we control for employee satisfaction and employee outlook for the same reason as in our future performance analysis. To be consistent with the definition of LargeGap, we use the average value from the past three years for all control variables.

Table 9 reports our results on the relation between the manager-employee expectation gap and CEO turnover. Panel A reports descriptive statistics of all variables used in the regression. The average CEO turnover rate is 0.10 , and about $16 \%$ of the firms have a large manager-employee expectation gap in the past three years. The average age of the CEOs is 56, and the average tenure is 7.4 years. Fifty-six percent of the CEOs also serve as the chairman of the board.

Panel B reports logit regression results. We find that the coefficient on LargeGap remains positive and significant in regressions that include CEO characteristics, employee overall satisfaction, and Outlook, respectively. These results suggest that a larger manager-employee expectation gap is associated with higher likelihood of future CEO turnover. In terms of economic magnitude, relative to firms without large manager-employer expectation gaps, the likelihood of CEO turnover in firms with large manager-employee expectation gaps is higher by 3.7 percentage points, equivalent to a 48 percent increase. Turning to control variables, consistent with our expectations, we find that future CEO turnover is negatively associated with past firm performance (measured by return on equity (ROE) and market-adjusted returns (CAR)), positively associated with CEO age and tenure, and negatively associated with CEO ownership. We also find that the likelihood of CEO turnover decreases with employee 
satisfaction in the past three years. Finally, we do not find a significant relation between CEO turnover and management forecast accuracy in our sample. ${ }^{9}$

\section{CONCLUSION}

In this study, we use employees’ predictions of firm business outlook from Glassdoor.com and management earnings forecasts to examine the existence, determinants, and consequences of information asymmetry between rank-and-file employees and top managers. We find that management earnings expectations do not fully incorporate employees’ information. We further observe that the information asymmetry between management and employees is alleviated by CEO's experience and internal engagement, employees' satisfaction, and organizational factors such as centralized decision making, better internal control, and use of stock options to incentivize employees. Finally, we document that firms with larger manageremployee expectation gaps have lower future performance and higher CEO turnover.

Our study takes an important step toward understanding intrafirm information asymmetry, and has important implications for both academics and practitioners. Organizational theory has long recognized that information is widely dispersed among firm employees. Extensive research has identified organizational designs that promote the use of appropriate organizational knowledge in decision-making. The large sample evidence from recent years in our study suggests that despite the substantial efforts made by organizational designers, significant information asymmetry still exists between management and employees within organizations, and that this asymmetry has significant negative consequences. The fact that the

\footnotetext{
${ }^{9}$ Our sample period of 2012-2017 is different from the sample period of 1996 and 2006 in Lee et al. (2012). In addition, we do not examine CEO turnover conditional on poor firm performance. These differences may explain why we do not find significant relation between management forecast accuracy and CEO turnover in our test.
} 
business outlook information disclosed by employees through social media is coarse and represents the lower bound of the information held by firm employees suggests that the asymmetry problem may be greater than is revealed in our study. Internal information asymmetry appears to be an important issue that warrants close attention from firm management. 


\section{REFERENCES}

Aboody, D., and R. Kasznik. 2000. CEO stock option awards and the timing of corporate voluntary disclosures. Journal of Accounting and Economics 29: 73-100.

Aghion, P., and J. Tirole. 1997. Formal and real Authority in organizations. Journal of Political Economy 105(1): 1-29.

Baiman, S., D. Larcker, and M. Rajan. 1995. Organizational design for business units. Journal of Accounting Research 33(2): 205-229.

Beneish, M., and M. Vargus. 2002. Insider trading, earnings quality, and accrual mispricing. The Accounting Review 77(4): 755-791.

Brickley, J., C. Smith, and J. Zimmerman. 2009. Managerial economics and organizational architecture. McGraw-Hill, New York, NY.

Chen, C., X. Martin, S. Roychowdhury, X. Wang, and M. Billett. 2018. Clarity begins at home: Internal information asymmetry and external communication quality. The Accounting Review 93 (1): 71-101.

Ciconte, W., M. Kirk, and J. Tucker. 2014. Does the midpoint of range earnings forecasts represent managers' expectations? Review of Accounting Studies 19: 628-660.

Cowgill, B., and E. Zitzewitz. 2015. Corporate prediction markets: Evidence from Google, Ford, and Firm X. Review of Economic Studies 82: 1309-1341.

Demsetz, H., and K. Lehn. 1985. The structure of corporate ownership: Causes and consequences. Journal of Political Economy 93 (6): 1155-1177.

Dorantes, C., C. Li, G. Peters, and V. Richardson. 2013. The effect of enterprise systems implementation on the firm information environment. Contemporary Accounting Research 30 (4): 1427-1461.

Dvorak, P. 2008. Best Buy taps “prediction market.” Wall Street Journal (September 16).

Edmans, A. 2011. Does the stock market fully value intangibles? Employee satisfaction and equity prices. Journal of Financial Economics 101 (3): 621-640.

Feng, M., C. Li, and S. McVay. 2009. Internal control and management guidance. Journal of Accounting and Economics 48 (2-3): 190-209.

Francis, J., D. Philbrick, and K. Schipper. 1994. Shareholder litigation and corporate disclosures. Journal of Accounting Research 32 (2): 137-164. 
Frankel, R., M. McNichols, and G. Wilson. 1995. Discretionary disclosure and external financing. The Accounting Review 70 (1): 135-150.

Frost, C. 1997. Disclosure policy choices of UK firms receiving modified audit reports. Journal of Accounting and Economics 23 (2): 163-187.

Gallemore, J. and E. Labro. 2015. The importance of the internal information environment for tax avoidance. Journal of Accounting and Economics 60: 149-167.

Garrett, J., R. Hoitash, and D. F. Prawitt. 2014. Trust and financial reporting quality. Journal of Accounting Research 52 (5): 1087-1125.

Gong, G., L. Li, and X. Hong. 2009. The association between management earnings forecast errors and accruals. The Accounting Review 84 (2): 497-530.

Gong, G., L. Li, and J. Wang. 2011. Serial correlation in management earnings forecast errors. Journal of Accounting Research 49 (3): 677-720.

Goodman, T. H., M. Neamtiu, N. Shroff, and H. White. 2014. Management forecast quality and capital investment decisions. Accounting Review 89 (1): 331-365.

Gow, I., G. Ormazabal, and D. Taylor. 2010. Correcting for cross-sectional and time-series dependence in accounting research. The Accounting Review 85 (2): 483-512.

Green, T., J. Russell, S. Markov, and M. Subasi. 2014. Broker-hosted investor conferences. Journal of Accounting and Economics 58: 142-166.

Hales, J., J. Moon, and L. Swenson. 2018. A new era of voluntary disclosure? Empirical evidence on the informativeness of rank-and-file employees' business outlook. Working paper, Georgia Institute of Technology.

Hofmann, C., and L. V. Lent. 2015. Organizational design and control choices. Oxford Handbooks. Oxford University Press, Oxford.

Huang, K., Li, M., and Markov, S. 2018. What do employees know? Evidence from a Social media platform. Working paper, University of Texas at Dallas.

Ittner, C. D., and J. Michels. 2017. Risk-based forecasting and planning and management earnings forecasts. Review of Accounting Studies 22 (3): 1005-1047.

Ke, R., M. Li, Z. Ling, and Y. Zhang. 2018. Social connections within executive teams and management forecasts. Management Science, forthcoming. 
Koch, A. 2002. Financial distress and the credibility of management earnings forecasts. Working paper, University of Virginia.

Lang, M., and R. Lundholm. 1996. Corporate disclosure policy and analyst behavior. The Accounting Review 71 (4): 476-492.

Lang, M., and R. Lundholm. 2000. Voluntary disclosure and equity offerings: Reducing information asymmetry or hyping the stock? Contemporary Accounting Research 17 (4): 623662.

Lee, S., S. Matsunaga, and C. Park. 2012. Management forecast accuracy and CEO turnover. The Accounting Review 87 (6): 2095-2122.

Li, F., M. Minnis, V. Nagar, and M. Rajan. 2014. Knowledge, compensation, and firm value: An empirical analysis of firm communication. Journal of Accounting and Economics 58 (1): 96-116.

Noe, C. 1999. Voluntary disclosures and insider transactions. Journal of Accounting and Economics 27: 305-327.

Prendergast, C. 1993. A theory of “yes men”. American Economic Review 83 (4): 757-770.

Rogers, J. L., and P. C. Stocken. 2005. Credibility of management forecasts. The Accounting Review 80: 1233-1260.

Sah, R., and J. Stiglitz. 1986. The architecture of economic systems: Hierarchies and polyarchies. The American Economic Review, 76 (4): 716-727.

Sheng, J. 2018. Asset pricing in the information age: Employee expectations and stock returns. Working paper, University of California at Irvine.

Wolfers, J., and E. Zitzewitz. 2004. Prediction markets. Journal of Economic Perspectives 18 (2): 107-126. 


\section{APPENDIX: Variable Definitions}

Variable

Outlook

MFE

LogMVE

MTB

$L E V$

$R O A$

SalesGrowth

Loss

TACC

RET

StdROA

StdRET

LitiRisk

$\operatorname{LogNUMA}$

Horizon
Definition

The average assessment of business outlook made by current employees within 30 days prior to the issuance date of management forecast. We code "getting better" as 1 , "staying the same" as 0 , and "getting worse" as -1 . Data source: Glassdoor

Management forecast error, measured as the actual earnings per share for year $t+1$ minus management earnings forecast for year $t+1$, scaled by the closing price at the end of year $t$. Data source: I/B/E/S Guidance

The natural logarithm of market value of equity (prcc_f*csho). Data source: Compustat

Market-to-book ratio, measured as market value of equity divided by the book value of equity (ceq). Data source: Compustat

Leverage ratio, calculated as long-term debt divided by total assets (dltt/at). Data source: Compustat

Return on asset, measured as income before extraordinary items (ib) divided by total assets at the beginning of the quarter (at). Data source: Compustat

Sales growth, measured as sales in year $\mathrm{t}$ minus sales in year $\mathrm{t}-1$, divided by sales in year t-1. Data source: Compustat

An indicator variable equal to one if earnings before extraordinary items are negative (ib), and zero otherwise. Data source: Compustat

Total accruals, measured as the difference between earnings (ib) and operating cash flows (oancf-xidoc), scaled by beginning total assets (ib). Data source: Compustat

Cumulative stock return over the fiscal year t. Data source: CRSP

Standard deviation of return on assets during the past five years. Data source: Compustat

Standard deviation of daily stock returns over the fiscal year t. Data source: CRSP

Litigation risk, measured as an indicator variable equal to one for litigious industries including Bio-Technology (SIC 2833 to 2836), Computer Hardware (SIC 3570 to 3577), Electronics (SIC 3600 to 3674), Retailing (SIC 5200 to 5961), and Computer Software (SIC 7370 to 7374), and zero otherwise. Data source: Compustat

The natural logarithm of the number of analysts following the company. Data source: I/B/E/S

Management forecast horizon, measured as the difference between fiscal year end of forecasting year and forecast issuance date, scaled by 365. Data source: I/B/E/S Guidance 


\section{Variables used in cross-sectional analysis}

Founder_CEO

CEO_Tenure

ExternalOriented_CEO

SeniorMgmt_D

Culture_D

Compensation_D

CareerOppor_D

SatisfFactor

Decentralization

IC_Weakness

EmpStockOption
An indicator variable equal to one if the CEO is a founder of the company, zero otherwise. Data source: https://site.warrington.ufl.edu/ritter/files/2018/04/FoundingDates.pdf and ExecuComp

An indicator variable equal to one if the CEO tenure is above sample median, zero otherwise. CEO tenure is measured as the number of years the CEO has worked in the company. Data source: ExecuComp

An indicator variable equal to one if the number of investor conferences the CEO attends is above sample median, and zero otherwise. Data source: Bloomberg Corporate Events Database.

An indicator variable equal to one if the average of the reviewers' fivepoint scale ratings on senior management is above sample median, zero otherwise. Data source: Glassdoor

An indicator variable equal to one if the average of the reviewers' fivepoint scale ratings on firm culture and value is above sample median, zero otherwise. Data source: Glassdoor

An indicator variable equal to one if the average of the reviewers' fivepoint scale ratings on compensation and benefits is above sample median, zero otherwise. Data source: Glassdoor

An indicator variable equal to one if the average of the reviewers' fivepoint scale ratings on career opportunities is above sample median, zero otherwise. Data source: Glassdoor

An indicator variable equal to one if the factor calculated based on senior management, culture \&value, compensation \& benefits, and career opportunities is above sample median, and zero otherwise. Data source: Glassdoor

An indicator variable equal to one if the firm decentralization score is above the median, zero otherwise. The decentralization score is computed as the first factor of principal component analysis based on the number of business segments, the number of geographic segments, and the number of employees. Data source: Compustat

An indicator variable equal to one if the firm discloses an internal control weakness, zero otherwise. Data source: AuditAnalytics

An indicator variable equal to one if the number of rank-and-file employee stock option is above sample median, and zero otherwise. Rank-and-file employee stock option is calculated as total employee stock options minus stock options owned by top executives, scaled by the number of shares outstanding. Data source: Compustat and ExecuComp

\section{Variables used in managerial incentive and insider trading analysis}

Financial Distress

Altman's Z score, computed as $(1.2 \times$ working capital/total assets +1.4 $\times$ retained earnings/total assets $+3.3 \times$ operating income/total assets + $0.6 \times$ market value of equity/total liabilities + sales/total assets). Data source: Compustat 


\section{External Financing}

Industry Concentration

Insider Selling

Purchase_Indicator

Purchase_Quantity
The sum of equity and debt financing scaled by lagged total assets, where equity financing equals cash proceeds from the sale of common and preferred stock minus cash payments for the purchase of common and preferred stock and cash payments for dividends, and net debt issuance equals cash proceeds from the issuance of long-term debt minus cash payments for long-term debt reductions and the net changes in current debt. Data source: Compustat

Industry concentration, measured by the Herfindahl-Hirschman index, calculated as the sum of the squares of the market shares of the firms' sales within each four-digit SIC industry. Data source: Compustat

Net abnormal sales made by CEOs and CFOs, measured as the number of net sales (i.e., number of shares sold minus number of shares purchased) made during the 30-day period following the management earnings forecast date, minus the number of net sales made during the 90-day period before management earnings forecast date, scaled by the number of shares outstanding. Data source: Thomson Financial

An indicator variable equal to one if CEO or CFO made any open market purchase in the 30 days following the issuance of management forecast date. Data source: Thomson Financial

Abnormal number of shares purchased by CEO and CFO, measured as the difference between shares purchased in the 30 days after the forecast issuance date and shares purchased in the 90 days before the issuance date, scaled by the number shares outstanding. Data source: Thomson Financial

\section{Variables used in future performance and turnover analysis}

LargeGap

Disagreement between management forecasts and employee outlook, measured as an indicator variable equal to one if management forecast error is in the most optimistic (pessimistic) quintile and employee outlook is in the most pessimistic (optimistic) quintile in any of the past three years, zero otherwise. Data source: I/B/E/S Guidance and Glassdoor

TobinQ

Market value of assets divided by book value of assets. Data source: Compustat

Tangible

$R \& D$

InstOwn

AbsMFE

CEO_Turnover
Net property, plant, and equipment, scaled by beginning assets. Data source: Compustat

Research and development expense (xrd), scaled by beginning sales Data source: Compustat

Institutional ownership, measured as the percentage of shares owned by institutional investors. Data source: Thomson Financial

Absolute value of management forecast error, measured as the actual earnings per share minus the first annual earnings forecast made during the forecasting year, scaled by stock price. Data source: I/B/E/S Guidance

An indicator variable equal to one if the CEO experiences a turnover in the fiscal year. Data source: Thomson Financial 
EmpOverallSatisf

$R O E$

$C A R$

LogSales

Age65

CEO_Ownership

CEOChair_Durality
Employee overall satisfaction, measured by the five-point scale overall ratings provided by current employee reviewers. Data source:

Glassdoor

Return on equity, measured as earnings before extraordinary items (ib) scaled by equity (ceq). Data source: Compustat

Cumulative market-adjusted abnormal return in a fiscal year. Data source: CRSP

The natural logarithm of sales. Data source: Compustat

An indicator variable equal to one if the age of the CEO is over 65, zero otherwise. Data source: ExecuComp

The number of stocks owned by CEO, scaled by the number of shares outstanding. Data source: ExecuComp

An indicator variable equal to one if the CEO is also a chairman of the board, zero otherwise. Data source: ExecuComp 
TABLE 1

Descriptive Statistics

\begin{tabular}{lrrrrrr}
\hline \hline & $\mathbf{N}$ & Mean & STD & P25 & Median & P75 \\
\hline MFE & 11,686 & 0.0010 & 0.0103 & 0.0000 & 0.0015 & 0.0041 \\
Outlook & 11,686 & 0.3084 & 0.5627 & 0.0000 & 0.3333 & 0.8000 \\
LogMVE & 11,686 & 8.6779 & 1.5192 & 7.6014 & 8.6592 & 9.7500 \\
MTB & 11,686 & 4.7495 & 7.8155 & 1.9093 & 3.0567 & 5.1210 \\
LEV & 11,686 & 0.2346 & 0.1695 & 0.1027 & 0.2276 & 0.3354 \\
ROA & 11,686 & 0.0623 & 0.0728 & 0.0293 & 0.0595 & 0.0956 \\
SalesGrowth & 11,686 & 0.0750 & 0.1473 & 0.0008 & 0.0516 & 0.1216 \\
Loss & 11,686 & 0.0954 & 0.2938 & 0.0000 & 0.0000 & 0.0000 \\
TACC & 11,686 & -0.0574 & 0.0578 & -0.0785 & -0.0485 & -0.0257 \\
RET & 11,686 & 0.1676 & 0.3066 & -0.0164 & 0.1467 & 0.3191 \\
StdROA & 11,686 & 0.0366 & 0.0504 & 0.0111 & 0.0207 & 0.0384 \\
StdRET & 11,686 & 0.0180 & 0.0072 & 0.0130 & 0.0164 & 0.0214 \\
LitiRisk & 11,686 & 0.3691 & 0.4826 & 0.0000 & 0.0000 & 1.0000 \\
LogNUMA & 11,686 & 2.5290 & 0.6351 & 2.1972 & 2.6391 & 2.9957 \\
Horizon & 11,686 & 0.5787 & 0.3455 & 0.3589 & 0.5836 & 0.8438 \\
\hline
\end{tabular}

This table reports descriptive statistics for the variables used in our main regression analyses. All variables are winsorized at $1 \%$ and $99 \%$ percentiles. Variable definitions are provided in the Appendix. 
TABLE 2

Management Forecast Error and Employee Outlook

\begin{tabular}{|c|c|c|c|}
\hline & \multicolumn{3}{|c|}{ Dependent Variable: $M F E_{t+1}$} \\
\hline & $(1)$ & $(2)$ & $(3)$ \\
\hline \multirow[t]{2}{*}{ Outlook30 } & $0.0017 * * *$ & $0.0009 * * *$ & $0.0011 * * *$ \\
\hline & $(3.46)$ & $(3.48)$ & $(4.78)$ \\
\hline \multirow[t]{2}{*}{ LogMVE } & & 0.0001 & $0.0003 *$ \\
\hline & & $(0.76)$ & $(1.66)$ \\
\hline \multirow[t]{2}{*}{ MTB } & & 0.0000 & 0.0000 \\
\hline & & $(0.44)$ & $(1.60)$ \\
\hline \multirow[t]{2}{*}{$L E V$} & & -0.0008 & -0.003 \\
\hline & & $(0.37)$ & $(1.60)$ \\
\hline \multirow[t]{2}{*}{$R O A$} & & $-0.0055 * * *$ & -0.0014 \\
\hline & & (2.59) & $(0.34)$ \\
\hline \multirow[t]{2}{*}{ SalesGrowth } & & -0.0027 & 0.001 \\
\hline & & (1.40) & $(0.66)$ \\
\hline \multirow[t]{2}{*}{ Loss } & & -0.0006 & $-0.0023 * *$ \\
\hline & & $(0.77)$ & $(2.26)$ \\
\hline \multirow[t]{2}{*}{ TACC } & & $-0.0087 * *$ & $-0.0134 * * *$ \\
\hline & & $(2.08)$ & $(3.55)$ \\
\hline \multirow[t]{2}{*}{$R E T$} & & 0.0015 & $0.0034 * * *$ \\
\hline & & $(1.57)$ & $(3.58)$ \\
\hline \multirow[t]{2}{*}{ StdROA } & & $0.022 * * *$ & $0.0222 * * *$ \\
\hline & & $(5.60)$ & $(4.70)$ \\
\hline \multirow[t]{2}{*}{ StdRET } & & $-0.1134 * *$ & $-0.2569 * * *$ \\
\hline & & $(2.12)$ & $(5.22)$ \\
\hline \multirow[t]{2}{*}{ LitiRisk } & & -0.0001 & 0.0008 \\
\hline & & $(0.09)$ & (1.03) \\
\hline \multirow[t]{2}{*}{ LogNUMA } & & 0.0002 & $0.0011^{* *}$ \\
\hline & & $(0.39)$ & $(2.16)$ \\
\hline \multirow[t]{2}{*}{ Horizon } & & $-0.0038 * * *$ & $-0.0054 * * *$ \\
\hline & & (4.98) & $(6.44)$ \\
\hline Industry/Time FE & Yes & Yes & Yes \\
\hline Observations & 11,686 & 11,686 & 11,686 \\
\hline Adjusted $\mathrm{R}^{2}$ & 0.005 & 0.05 & 0.12 \\
\hline
\end{tabular}

This table presents results from OLS regressions of management forecast errors on employee outlook. Detailed variable definitions are in the Appendix. Fama-French 48 industry fixed effects and year fixed effects are included. t-statistics are reported in parentheses. Standard errors are clustered by firm and year. Significance at the $10 \%, 5 \%$, and $1 \%$ level is denoted with *, **, and $* * *$, respectively. 
TABLE 3

Management Forecast Error and Employee Outlook - CEO Attribute Analysis

\begin{tabular}{lrrrrrr}
\hline \multicolumn{7}{l}{ Panel A: Descriptive Statistics of CEO attributes } \\
\hline N & Mean & STD & P25 & Median & \multicolumn{1}{c}{ P75 } \\
\hline Founder & 5,056 & 0.1847 & 0.3881 & 0 & 0 & 0 \\
Tenure & 9,471 & 7.3680 & 6.7203 & 2.6356 & 5.2521 & 9.8521 \\
No. of Conferences & 9,202 & 6.8935 & 5.1808 & 3 & 6 & 9 \\
\hline
\end{tabular}

Panel B: Regression Results

\begin{tabular}{lccc}
\hline & \multicolumn{3}{c}{ Dependent Variable: MFE E $_{t+1}$} \\
\cline { 2 - 4 } & $0.0014^{*}$ & $(2)$ & $(3)$ \\
\hline Outlook & $(1.71)$ & $(3.32)$ & $0.0003^{* * * *}$ \\
Founder_CEO & .0017 & & $(2.58)$ \\
& $(1.39)$ & & \\
Outlook*Founder_CEO & $-0.0029^{* *}$ & & \\
& $(2.01)$ & & \\
CEO_Tenure & & 0.0001 & \\
& & $(0.18)$ & \\
Outlook*CEO_Tenure & & $-0.0017^{* * *}$ & -0.0002 \\
& & $(2.97)$ & $(0.63)$ \\
ExternalOriented_CEO & & & $0.0006^{* * *}$ \\
& & & $(3.35)$ \\
Outlook*ExternalOriented_CEO & & & Yes \\
& & Yes & Yes \\
Controls & Yes & 9,471 & 9,202 \\
Industry/Time FE & Yes & 0.065 & 0.067 \\
Observations & 5,056 & & \\
Adjusted R & & & \\
\hline
\end{tabular}

This table examines whether the association between management forecast errors and employee outlook varies with CEO attributes. Panel A presents the descriptive statistics of CEO attributes. Panel B presents the regression results of management forecast errors on employee outlook conditional on CEO attributes. Founder_CEO is an indicator variable equal to one if the CEO is a founder of the company, and zero otherwise. CEO_Tenure is an indicator variable equal to one if the CEO tenure is above sample median, and zero otherwise. ExternalOriented_CEO is an indicator variable equal to one if the number of conferences the CEO attends is above sample median, and zero otherwise. All control variables are the same as in Table 2, and detailed variable definitions are in the Appendix. Fama-French 48 industry fixed effects and year fixed effects are included. t-statistics are reported in parentheses. Standard errors are clustered by firm and year. Significance at the $10 \%, 5 \%$, and $1 \%$ level is denoted with *, **, and ***, respectively. 
TABLE 4

Management Forecast Error and Employee Outlook: Employee Satisfaction Analysis

Panel A: Descriptive Statistics on Employee Satisfaction

\begin{tabular}{lcccccc}
\hline & $\mathbf{N}$ & Mean & STD & 25th & 50th & 75th \\
\hline SeniorMgmt & 11,629 & 2.9734 & 0.9938 & 2.3333 & 3.0000 & 3.6667 \\
Culture & 11,629 & 3.3373 & 1.0187 & 2.7857 & 3.4167 & 4.0000 \\
Compensation & 11,633 & 3.3528 & 0.8792 & 2.9853 & 3.4000 & 4.0000 \\
CareerOppor & 11,631 & 3.1538 & 0.9374 & 2.6000 & 3.1111 & 3.8333 \\
\hline
\end{tabular}

Panel B: Regression Analysis

\begin{tabular}{|c|c|c|c|c|c|}
\hline & \multicolumn{5}{|c|}{ Dependent Variable: $M F E_{t+1}$} \\
\hline & $(1)$ & $(2)$ & (3) & $(4)$ & (5) \\
\hline Outlook & $\begin{array}{l}0.001^{* * *} \\
(6.05)\end{array}$ & $\begin{array}{l}0.0007 * * * \\
(3.82)\end{array}$ & $\begin{array}{l}0.0005^{* * * *} \\
(3.76)\end{array}$ & $\begin{array}{l}0.0006^{* * * *} \\
(4.89)\end{array}$ & $\begin{array}{l}0.0010^{* * *} \\
(6.42)\end{array}$ \\
\hline SeniorMgmt_D & $\begin{array}{c}0.0007^{*} \\
(1.88)\end{array}$ & & & & \\
\hline Outlook*SeniorMgmt_D & $\begin{array}{l}-0.0009 * * * \\
(10.15)\end{array}$ & & & & \\
\hline Culture_D & & $\begin{array}{r}0.0001 \\
(0.59)\end{array}$ & & & \\
\hline Outlook*Culture_D & & $\begin{array}{c}-0.0005^{* *} \\
(2.04)\end{array}$ & & & \\
\hline Compensation_D & & & $\begin{array}{c}0.0002^{* *} \\
(2.37)\end{array}$ & & \\
\hline Outlook*Compensation_D & & & $\begin{array}{c}-0.0003^{* *} \\
(2.00)\end{array}$ & & \\
\hline CareerOpp_D & & & & $\begin{array}{r}0.0000 \\
(0.03)\end{array}$ & \\
\hline Outlook*CareerOpp_D & & & & $\begin{array}{r}-0.0002 \\
(1.18)\end{array}$ & \\
\hline SatisfFactor & & & & & $\begin{array}{r}0.0003 \\
(0.85)\end{array}$ \\
\hline Outlook*SatisfFactor & & & & & $\begin{array}{c}-0.0007^{* *} \\
(3.16)\end{array}$ \\
\hline Controls & Yes & Yes & Yes & Yes & Yes \\
\hline Industry/Time FE & Yes & Yes & Yes & Yes & Yes \\
\hline Observations & 11,629 & 11,629 & 11,633 & 11,631 & 11,092 \\
\hline Adjusted $\mathrm{R}^{2}$ & 0.054 & 0.054 & 0.05 & 0.051 & 0.053 \\
\hline
\end{tabular}

This table examines whether the association between management forecast error and employee outlook varies with employee satisfaction. Panel A presents the descriptive statistics of employee five-point scale satisfaction scores. Panel B presents the regression results of management forecast error on employee outlook conditional on employee satisfaction. In Panel B, each employee satisfaction variable (i.e., SeniorMgmt_D, Culture_D, Compensation_D, and CareerOpp_D) is an indicator variable equal to one if 
the corresponding satisfaction score is above the sample median, and zero otherwise. SatisfFactor is an indicator variable equal to one if the factor calculated based on principal component analysis of senior management; culture and value; compensation and benefits; and career opportunities is above sample median, and zero otherwise. All control variables are the same as in Table 2, and detailed variable definitions are in the Appendix. Fama-French 48 industry fixed effects and year fixed effects are included. t-statistics are reported in parentheses. Standard errors are clustered by firm and year. Significance at the $10 \%, 5 \%$, and $1 \%$ level is denoted with *, **, and ***, respectively. 
TABLE 5

Management Forecast Error and Employee Outlook: Firm Characteristics Analysis

Panel A: Descriptive Statistics on Firm Characteristics

\begin{tabular}{lcccccr}
\hline & N & Mean & STD & 25th & 50th & 75th \\
\hline No. of Business Segments & 8,610 & 2.5995 & 1.6291 & 1 & 2 & 4 \\
No. of Geographic Segments & 8,610 & 3.3976 & 2.4117 & 1 & 3 & 5 \\
No. of Employees & 8,610 & 35.766 & 60.615 & 5.558 & 13.500 & 37.300 \\
IC_Weakness & 11,399 & 0.0361 & 0.1864 & 0 & 0 & 0 \\
RF_StockOption & 9,774 & 0.0360 & 0.0320 & 0.0113 & 0.0300 & 0.0513 \\
\hline
\end{tabular}

Panel B: Regression Analysis

\begin{tabular}{|c|c|c|c|}
\hline & Depen & Variable: $\boldsymbol{N}$ & \\
\hline & $(1)$ & $(2)$ & (3) \\
\hline Outlook & $\begin{array}{c}0.0007 * \\
(1.81)\end{array}$ & $\begin{array}{l}0.001 \\
(1.44)\end{array}$ & $\begin{array}{l}0.0011^{* * * *} \\
(3.59)\end{array}$ \\
\hline Decentralization & $\begin{array}{c}-0.0012 * * * \\
(2.64)\end{array}$ & & \\
\hline Outlook*Decentralization & $\begin{array}{l}0.0004^{* *} \\
(2.22)\end{array}$ & & \\
\hline IC_Weakness & & $\begin{array}{c}-0.0068 * * * \\
(2.92)\end{array}$ & \\
\hline Outlook*IC_Weakness & & $\begin{array}{c}0.0046 * \\
(1.74)\end{array}$ & \\
\hline EmpStockOption & & & $\begin{array}{r}0.0001 \\
(0.31)\end{array}$ \\
\hline Outlook*EmpStockOption & & & $\begin{array}{c}-0.0007 * * \\
(2.43)\end{array}$ \\
\hline Controls & Yes & Yes & Yes \\
\hline Industry/Time FE & Yes & Yes & Yes \\
\hline Observations & 8,610 & 11,399 & 9,774 \\
\hline Adjusted $\mathrm{R}^{2}$ & 0.061 & 0.031 & 0.054 \\
\hline
\end{tabular}

This table examines whether the association between management forecast error and employee outlook varies with firm characteristics. Panel A presents the descriptive statistics of firm characteristics. Panel B presents the regression results of management forecast error on employee outlook conditional on firm characteristics. Decentralization is an indicator variable equal to one when the first factor derived from principal component analysis based on the number of business segments, geographic segments, and employees is above sample median. IC_Weakness is an indicator variable equal to one if the firm discloses an internal control weakness, and zero otherwise. EmpStockOption is an indicator variable equal to one when the number of rank-and-file employee stock option is above the sample median. All control variables are the same as in Table 2, and detailed variable definitions are in the Appendix. Fama-French 48 industry fixed effects and year fixed effects are included. t-statistics are reported in parentheses. Standard errors are clustered by firm and year. Significance at the $10 \%, 5 \%$, and $1 \%$ level is denoted with $*$, **, and ***, respectively. 
TABLE 6

Management Forecast Error and Employee Outlook: Managerial Incentive Analysis

Dependent Variable: $M F E_{t+1}$

\begin{tabular}{|c|c|c|c|c|}
\hline & \\
\hline & \multicolumn{4}{|c|}{ Subsample: } \\
\hline & High & High & High & High \\
\hline & Financial & External & Industry & Insider \\
\hline & Distress & Financing & Competition & Selling \\
\hline & $(1)$ & $(2)$ & (3) & $(4)$ \\
\hline \multirow{2}{*}{ Outlook } & 0.0010** & $0.0011 * * *$ & $0.0008 * * *$ & $0.0003 * *$ \\
\hline & $(2.44)$ & $(4.45)$ & $(2.80)$ & (1.98) \\
\hline \multirow[t]{2}{*}{ Size } & 0.0005 & 0.0003 & 0.0002 & 0.0000 \\
\hline & (1.15) & (1.48) & $(0.52)$ & $(0.08)$ \\
\hline \multirow[t]{2}{*}{ MTB } & $0.0000 * *$ & 0.0000 & 0.0000 & 0.0000 \\
\hline & $(1.96)$ & (1.26) & (1.03) & $(0.37)$ \\
\hline \multirow[t]{2}{*}{$L E V$} & 0.0012 & 0.0002 & -0.0011 & 0.001 \\
\hline & $(0.39)$ & $(0.08)$ & $(0.43)$ & $(0.86)$ \\
\hline \multirow[t]{2}{*}{$R O A$} & $-0.0165 * *$ & -0.0035 & $-0.0086 * *$ & $-0.0041 * *$ \\
\hline & $(2.12)$ & (1.02) & $(2.43)$ & (2.12) \\
\hline \multirow[t]{2}{*}{$S G$} & $-0.0047 * * *$ & $-0.0038 * * *$ & $-0.0036 * * *$ & $-0.0034 * *$ \\
\hline & (3.91) & (2.73) & $(4.10)$ & $(2.55)$ \\
\hline \multirow[t]{2}{*}{ Loss } & 0.0008 & 0.0002 & 0.0003 & -0.0006 \\
\hline & $(0.49)$ & $(0.11)$ & $(0.22)$ & $(0.88)$ \\
\hline \multirow[t]{2}{*}{ TACC } & 0.0104 & -0.0016 & 0.0031 & -0.0008 \\
\hline & (1.03) & (0.37) & $(0.78)$ & $(0.24)$ \\
\hline \multirow[t]{2}{*}{ RET } & $0.003 * * *$ & $0.0023 * * *$ & 0.0012 & $0.0016 * *$ \\
\hline & $(3.57)$ & $(5.87)$ & (1.5) & $(2.50)$ \\
\hline \multirow[t]{2}{*}{ StdROA } & $0.025 * * *$ & $0.0203 * * *$ & $0.024 * * *$ & $0.0173 * * *$ \\
\hline & $(3.36)$ & $(5.12)$ & $(6.00)$ & $(6.97)$ \\
\hline \multirow[t]{2}{*}{ StdRET } & 0.0595 & 0.0032 & -0.0052 & -0.0051 \\
\hline & $(0.79)$ & $(0.07)$ & $(0.13)$ & $(0.24)$ \\
\hline \multirow[t]{2}{*}{ LitiRisk } & 0.0004 & $0.0015^{* *}$ & -0.0001 & 0.0006 \\
\hline & $(0.44)$ & $(2.44)$ & $(0.07)$ & $(0.92)$ \\
\hline \multirow[t]{2}{*}{ LogNUMA } & 0.0005 & 0.0003 & 0.0002 & 0.0002 \\
\hline & $(0.61)$ & $(0.60)$ & $(0.42)$ & $(0.35)$ \\
\hline \multirow[t]{2}{*}{ Horizon } & $-0.0037 * * *$ & $-0.0021 * * *$ & -0.0009 & $-0.0014^{* * *}$ \\
\hline & $(3.33)$ & (2.98) & $(0.97)$ & $(2.70)$ \\
\hline Industry/Time FE & Yes & Yes & Yes & Yes \\
\hline Observations & 3,229 & 4,854 & 3,750 & 5,283 \\
\hline Adjusted $\mathrm{R}^{2}$ & 0.111 & 0.076 & 0.075 & 0.063 \\
\hline
\end{tabular}

This table presents results from OLS regressions of management forecast error on employee outlook when employee outlook is positive and managers have incentives to incorporate good news in their 
forecasts. In Column (1), high financial distress subsample includes observations with Z-score above the sample median. In Column (2), high external financing subsample includes observations with firm equity and debt issuance above the sample median. In Column (3), high industry competition subsample

includes observations with the Herfindahl-Hirschman index below the sample median. In Column (4), high insider selling subsample includes observations with net insider (i.e., CEO and CFO) selling above the sample median. All control variables are the same as in Table 2, and detailed variable definitions are in the Appendix. Fama-French 48 industry fixed effects and year fixed effects are included. t-statistics are reported in parentheses. Standard errors are clustered by firm and year. Significance at the $10 \%, 5 \%$, and $1 \%$ level is denoted with $*$, ${ }^{* *}$, and ${ }^{* * *}$, respectively. 
TABLE 7

Insider Trading and Employee Outlook

\begin{tabular}{|c|c|c|c|}
\hline & $\begin{array}{l}\text { Purchase } \\
\text { Indicator }\end{array}$ & $\begin{array}{c}\text { Dependent Variable: } \\
\text { Purchase } \\
\text { Quantity }\end{array}$ & $\begin{array}{c}\text { Purchase } \\
\text { Quantity }\end{array}$ \\
\hline & $(1)$ & $(2)$ & (3) \\
\hline \multirow[t]{2}{*}{ Outlook } & -0.0876 & 0.0001 & -0.0005 \\
\hline & $(1.43)$ & $(0.53)$ & $(0.57)$ \\
\hline \multirow[t]{2}{*}{ Size } & -0.0701 & 0.0003 & 0.001 \\
\hline & (1.61) & $(0.88)$ & $(0.59)$ \\
\hline \multirow[t]{2}{*}{ MTB } & 0.0003 & 0.0000 & -0.0001 \\
\hline & $(0.26)$ & (1.17) & (1.11) \\
\hline \multirow[t]{2}{*}{$L E V$} & 0.1418 & 0.0004 & 0.0036 \\
\hline & $(0.80)$ & $(0.45)$ & $(0.87)$ \\
\hline \multirow[t]{2}{*}{$R O A$} & -0.7666 & $0.0097 *$ & $0.0408 * *$ \\
\hline & (1.58) & $(1.93)$ & $(2.46)$ \\
\hline \multirow[t]{2}{*}{$S G$} & $-0.2761^{*}$ & -0.0016 & -0.007 \\
\hline & (1.77) & $(0.69)$ & $(0.78)$ \\
\hline \multirow[t]{2}{*}{ Loss } & 0.0722 & -0.0014 & $-0.0053^{* * *}$ \\
\hline & $(0.45)$ & (1.08) & (3.55) \\
\hline \multirow[t]{2}{*}{ TACC } & 0.6047 & $-0.0101^{* * *}$ & $-0.0339 * *$ \\
\hline & (1.09) & (3.69) & $(2.14)$ \\
\hline \multirow[t]{2}{*}{ RET } & $-0.1513 * * *$ & 0.0015 & $0.0063^{* *}$ \\
\hline & $(2.71)$ & (1.63) & (2.48) \\
\hline \multirow[t]{2}{*}{ StdROA } & 0.4393 & -0.002 & -0.0206 \\
\hline & $(0.63)$ & $(0.60)$ & (1.07) \\
\hline \multirow[t]{2}{*}{ StdRET } & $17.0462 * * *$ & 0.0062 & 0.1042 \\
\hline & $(2.90)$ & $(0.09)$ & $(0.32)$ \\
\hline \multirow[t]{2}{*}{ LitiRisk } & $-0.2512^{* *}$ & 0.0005 & 0.0021 \\
\hline & $(2.58)$ & $(0.45)$ & $(0.53)$ \\
\hline \multirow[t]{2}{*}{$\log N U M A$} & -0.0796 & 0.0004 & 0.0013 \\
\hline & $(0.82)$ & $(0.56)$ & $(0.38)$ \\
\hline \multirow[t]{2}{*}{ Horizon } & $-0.0865^{*}$ & 0.0008 & 0.0032 \\
\hline & (1.76) & $(0.93)$ & $(0.84)$ \\
\hline Industry/Time FE & Yes & Yes & Yes \\
\hline Observations & 11,248 & 11,686 & 5,624 \\
\hline Adjusted $\mathrm{R}^{2}$ & 0.089 & 0.001 & 0.001 \\
\hline
\end{tabular}

This table examines the association between insider purchases and employee outlook. In Column (1), the dependent variable Purchase_Indicator is an indicator variable equal to one if the CEO or CFO made any open market purchase in the 30 days following the issuance of management forecast date. In Columns (2) and (3), the dependent variable Purchase_Quantity is the abnormal number of shares purchased by the 
CEO and CFO, measured as the difference between shares purchased in the 30 days after the forecast issuance date and shares purchased in the 90 days before the forecast issuance date, scaled by the number of shares outstanding. Outlook is the average value of outlook assessments made by current employees 30 days prior to the forecast issuance date. In Column (2), Purchase_Quantity is coded as zero for observations with no trading activities. In Column (3), observations with no trading activities are excluded. All control variables are the same as in Table 2, and detailed variable definitions are in the Appendix. Fama-French 48 industry fixed effects and year fixed effects are included. t-statistics are reported in parentheses. Standard errors are clustered by firm and year. Significance at the 10\%, 5\%, and $1 \%$ level is denoted with $*$, **, and ${ }^{* * *}$, respectively. 
TABLE 8

Consequences of Expectation Gaps between Management and Employees:

Future Performance Analysis

\begin{tabular}{lcccccc}
\hline \hline \multicolumn{2}{l}{ Panel A: Descriptive Statistics } & \multicolumn{7}{l}{ (5)th } \\
\hline ROA & $\mathbf{N}$ & Mean & STD & 25th & 50th & 75th \\
TobinQ & 2,673 & 0.0506 & 0.0806 & 0.0227 & 0.0515 & 0.0890 \\
LargeGap & 2,673 & 2.2574 & 1.2781 & 1.3756 & 1.8268 & 2.6878 \\
Size & 2,673 & 0.1620 & 0.3685 & 0.0000 & 0.0000 & 0.0000 \\
LEV & 2,673 & 8.3075 & 1.5193 & 7.2068 & 8.2104 & 9.3362 \\
SalesGrowth & 2,673 & 0.2181 & 0.1688 & 0.0824 & 0.2047 & 0.3143 \\
Tangible & 2,673 & 0.0766 & 0.1220 & 0.0056 & 0.0559 & 0.1266 \\
R\&D & 2,673 & 0.2191 & 0.2055 & 0.0712 & 0.1425 & 0.2942 \\
StdRet & 2,673 & 0.0270 & 0.0465 & 0.0000 & 0.0019 & 0.0338 \\
InstOwn & 2,673 & 0.0192 & 0.0072 & 0.0140 & 0.0177 & 0.0230 \\
AbsMFE & 2,673 & 0.7085 & 0.1660 & 0.6106 & 0.7355 & 0.8228 \\
EmpOverallSatisf & 2,673 & 0.0083 & 0.0145 & 0.0022 & 0.0042 & 0.0083 \\
Outlook & 2,673 & 3.2916 & 0.7312 & 2.8810 & 3.3333 & 3.7647 \\
\hline
\end{tabular}

Panel B: Regression Analysis

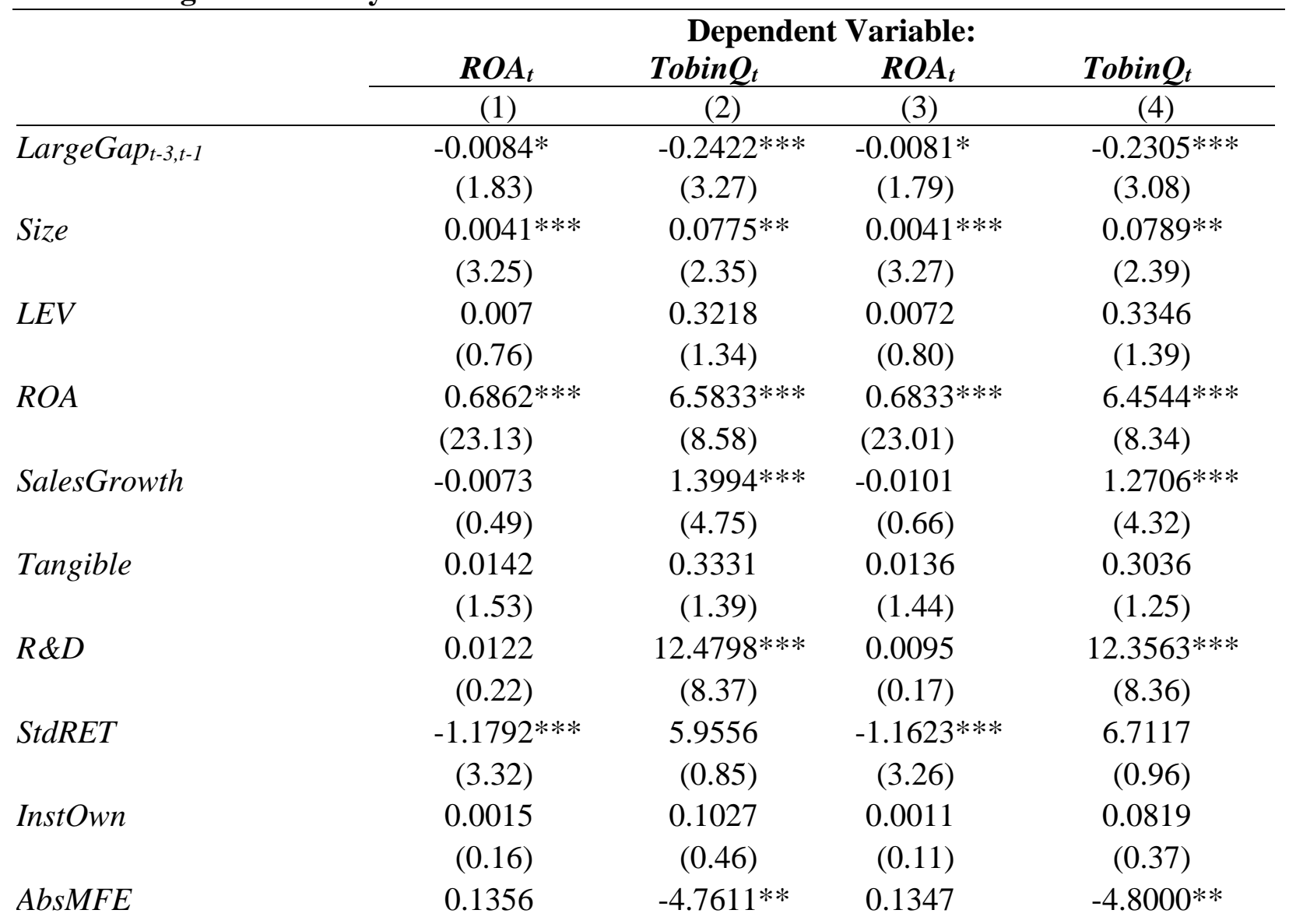




\begin{tabular}{lcccc} 
& $(0.90)$ & $(2.46)$ & $(0.90)$ & $(2.45)$ \\
EmpOverallSatisf & $0.0034^{*}$ & $0.1777^{* * *}$ & 0.0015 & $0.0935^{*}$ \\
Outlook & $(1.75)$ & $(3.96)$ & $(0.58)$ & $(1.68)$ \\
& & & 0.0048 & $0.2155^{* *}$ \\
Industry/Time FE & & & $(1.07)$ & $(2.44)$ \\
Observations & Yes & Yes & Yes & Yes \\
Adjusted R & 2,673 & 2,673 & 2,673 & 2,673 \\
\hline
\end{tabular}

This table examines the association between the expectation gap between management and employees and firm future performance. Panel A presents descriptive statistics of all variables. Panel B presents results from OLS regressions of firm future performance on the expectation gap. $R O A$ is the return on assets in the current year. TobinQ is Tobin's Q in the current year. LargeGap is an indicator variable equal to one if management forecast error is in the most optimistic (pessimistic) quintile and employee outlook is in the most pessimistic (optimistic) quintile in any of the past three years, and zero otherwise. All control variables are calculated as the average over the past three years. Detailed variable definitions are in the Appendix. Fama-French 48 industry fixed effects and year fixed effects are included. t-statistics are reported in parentheses. Standard errors are clustered by firm. Significance at the $10 \%, 5 \%$, and $1 \%$ level is denoted with $*$, **, and $* * *$, respectively. 
TABLE 9

Consequences of Expectation Gaps between Management and Employees:

CEO Turnover Analysis

\begin{tabular}{lcccrrr}
\hline \hline \multicolumn{1}{l}{ Panel A: Descriptive Statistics } & \multicolumn{1}{c}{ N } & Mean & STD & 25th & 50th & 75th \\
\hline CEO_Turnover & 1,561 & 0.1044 & 0.3059 & 0 & 0 & 0 \\
LargeGap & 1,561 & 0.1585 & 0.3653 & 0 & 0 & 0 \\
ROE & 1,561 & 0.0502 & 0.0493 & 0.0402 & 0.0556 & 0.0700 \\
CAR & 1,561 & 0.0522 & 0.1617 & -0.0437 & 0.0400 & 0.1376 \\
LogSales & 1,561 & 8.2253 & 1.4604 & 7.2462 & 8.1990 & 9.2301 \\
StdROA & 1,561 & 0.0344 & 0.0388 & 0.0125 & 0.0214 & 0.0396 \\
StdRet & 1,561 & 0.0176 & 0.0061 & 0.0131 & 0.0165 & 0.0208 \\
InstOwn & 1,561 & 0.7234 & 0.1519 & 0.6304 & 0.7441 & 0.8256 \\
AbsMFE & 1,561 & 0.0079 & 0.0138 & 0.0022 & 0.0040 & 0.0083 \\
Age & 1,561 & 56.3822 & 6.5172 & 52 & 56 & 60 \\
Age65 & 1,561 & 0.0909 & 0.2876 & 0 & 0 & 0 \\
Tenure & 1,561 & 7.3680 & 6.7203 & 2.6356 & 5.2521 & 9.8520 \\
CEO_Ownership & 1,561 & 0.0138 & 0.0354 & 0.0008 & 0.0024 & 0.0076 \\
CEOChair_Duality & 1,561 & 0.5608 & 0.4964 & 0 & 1 & 1 \\
EmpOverallSatisf & 1,561 & 3.2660 & 0.7761 & 2.8333 & 3.3333 & 3.7736 \\
Outlook & 1,561 & 0.2379 & 0.4636 & 0 & 0.2564 & 0.5338 \\
\hline
\end{tabular}

Panel B: Regression Analysis

\begin{tabular}{lcccc}
\hline & \multicolumn{3}{c}{ Dependent Variable: CEO_Turnover } \\
\cline { 2 - 5 } & $(1)$ & $(2)$ & $(3)$ & $(4)$ \\
\hline LargeGap $_{t-3, t-1}$ & $0.4208^{* *}$ & $0.5092^{* *}$ & $0.4329^{* *}$ & $0.4365^{* * *}$ \\
& $(2.07)$ & $(2.38)$ & $(2.00)$ & $(2.03)$ \\
ROE & $-3.6065^{* *}$ & $-4.0334^{* * *}$ & $-3.8825^{* * *}$ & $-3.9406^{* * *}$ \\
& $(2.39)$ & $(2.80)$ & $(2.73)$ & $(2.74)$ \\
CAR & $-1.8301^{* * *}$ & $-1.9159^{* * *}$ & $-1.9035^{* * *}$ & $-1.9229 * * *$ \\
& $(3.03)$ & $(2.89)$ & $(2.86)$ & $(2.80)$ \\
LogSales & 0.0622 & 0.0617 & 0.0798 & 0.0813 \\
& $(0.94)$ & $(0.87)$ & $(1.14)$ & $(1.15)$ \\
StdROA & $4.07 *$ & $4.611^{*}$ & $4.9247^{* *}$ & $4.8839 * *$ \\
& $(1.91)$ & $(1.81)$ & $(2.03)$ & $(2.04)$ \\
StdRET & -4.0479 & 12.7947 & 10.0446 & 10.1881 \\
& $(0.22)$ & $(0.66)$ & $(0.51)$ & $(0.52)$ \\
InstOwn & 0.4329 & 0.224 & 0.3091 & 0.3057 \\
AbsMFE & $(0.75)$ & $(0.37)$ & $(0.52)$ & $(0.52)$ \\
& 2.0259 & -3.4375 & -3.3444 & -3.2837
\end{tabular}




\begin{tabular}{|c|c|c|c|c|}
\hline \multicolumn{2}{|l|}{ CEOAge } & $\begin{array}{l}0.0537^{* * *} \\
(3.34)\end{array}$ & $\begin{array}{l}0.052^{* * *} \\
(3.19)\end{array}$ & $\begin{array}{l}0.0522 * * * \\
(3.21)\end{array}$ \\
\hline \multicolumn{2}{|l|}{ CEOAge65 } & $\begin{array}{l}0.68 * * * \\
(2.68)\end{array}$ & $\begin{array}{l}0.7206^{* * * *} \\
(2.85)\end{array}$ & $\begin{array}{l}0.721 * * * \\
(2.85)\end{array}$ \\
\hline \multicolumn{2}{|l|}{ Tenure } & $\begin{array}{l}0.0001^{* * *} \\
(3.27)\end{array}$ & $\begin{array}{l}0.0001^{* * *} \\
(3.34)\end{array}$ & $\begin{array}{l}0.0001^{* * *} \\
(3.34)\end{array}$ \\
\hline \multicolumn{2}{|l|}{ CEO_Ownership } & $\begin{array}{c}-13.0557^{* * *} \\
(2.65)\end{array}$ & $\begin{array}{c}-12.9732^{* *} \\
(2.50)\end{array}$ & $\begin{array}{c}-12.9637 * * \\
(2.50)\end{array}$ \\
\hline \multicolumn{2}{|l|}{ CEOChair_Duality } & $\begin{array}{r}-0.0963 \\
(0.50)\end{array}$ & $\begin{array}{r}-0.0957 \\
(0.49)\end{array}$ & $\begin{array}{r}-0.0975 \\
(0.50)\end{array}$ \\
\hline \multicolumn{2}{|l|}{ EmpOverallSatisf } & & $\begin{array}{c}-0.2928^{* * * *} \\
(2.82)\end{array}$ & $\begin{array}{c}-0.3142 * * \\
(2.21)\end{array}$ \\
\hline \multicolumn{2}{|l|}{ Outlook } & & & $\begin{array}{r}0.0538 \\
(0.22)\end{array}$ \\
\hline Industry/Time FE & Yes & Yes & Yes & Yes \\
\hline Observations & 1,561 & 1,561 & 1,561 & 1,561 \\
\hline Adjusted $\mathrm{R}^{2}$ & 0.065 & 0.109 & 0.114 & 0.114 \\
\hline
\end{tabular}

This table examines the association between the expectation gap between management and employees and future CEO turnover. Panel A presents descriptive statistics of all variables. Panel B presents results from logit regressions of CEO turnover on expectation gap between management and employees. CEO_Turnover is an indicator equal to one if the firm experiences a CEO turnover in the current year, and zero otherwise. LargeGap is an indicator variable equal to one if management forecast error is in the most optimistic (pessimistic) quintile and employee outlook is in the most pessimistic (optimistic) quintile in any of the past three years, and zero otherwise. All control variables are calculated as the average over the past three years, except that CEOChair_Duality and CEOAge65 are equal to one if they take the value of one in any of the past three years. Detailed variable definitions are in the Appendix. Fama-French 48 industry fixed effects and year fixed effects are included. t-statistics are reported in parentheses. Standard errors are clustered by firm. Significance at the $10 \%, 5 \%$, and $1 \%$ level is denoted with *, **, and ***, respectively. 